Open Access at : http://jurnal.umt.ac.id/index.php/replik/article/view/1446

\title{
KEWENANGAN DAN PERAN PEMERINTAH DALAM PENYELENGGARAAN KOMEPETISI SEPAK BOLA DI INDONESIA (THE AUTHORITY AND ROLE OF GOVERNMENT IN THE ORGANIZING OF FOOTBALL COMPETITION IN INDONESIA)
}

\author{
Muhammad Zulhidayat \\ Fakultas Hukum Universitas Muhammadiyah Tangerang \\ E-Mail: zulhidayat007@gmail.com
}

\begin{abstract}
Abstrak
Pada 30 Mei 2015, FIFA sebagai induk tertinggi dari organisasi sepakbola internasional menjatuhkan sanksi kepada PSSI. Ini terjadi karena FIFA menilai adanya intervensi oleh pemerintah melalui Kementerian Pemuda dan Olahraga. Statuta FIFA pasal 13 dan 17 memperjelas bahwa ia menolak segala bentuk intervensi oleh pemerintah, politisi, media, atau pihak ketiga lainnya. Di sisi lain, Kementerian Pemuda dan Olahraga juga diberi wewenang oleh hukum untuk mengatur kegiatan olahraga secara umum dalam lingkup Negara Indonesia. Permasalahan yang akan dikaji dalam penelitian ini adalah sebagai berikut: Pertama, apa wewenang dan peran pemerintah dalam menyelenggarakan olahraga sepakbola profesional di Indonesia? Kedua, bagaimana penerapan kompetisi sepakbola di Indonesia dengan adanya Pembekuan PSSI? . Metode penelitian dalam penulisan ini menggunakan metode yuridis normatif. Kesimpulan dari penelitian ini adalah bahwa Pemerintah tidak memiliki wewenang untuk campur tangan dan ikut campur dalam menyelenggarakan kompetisi sepakbola profesional di Indonesia. Sementara itu, dengan pembekuan PSSI ini, otomatis menghentikan liga karena PSSI tidak dapat melakukan tugas dan fungsi untuk mengadakan kompetisi sepakbola profesional di Indonesia. Saran penulis dalam penelitian ini adalah Pemerintah harus optimal dalam memberikan layanan dan kenyamanan kepada PSSI dan PSSI harus transparan dalam menyelenggarakan kompetisi sepakbola profesional di Indonesia.
\end{abstract}

Kata Kunci : Kewenangan, Pemerintah, PSSI

\begin{abstract}
On May 30, 2015, FIFA as the supreme parent of international football organizations imposed sanctions on the PSSI. This happens because FIFA assess
\end{abstract}


the existence of intervention by the government through the Ministry of Youth and Sports. The FIFA Statutes chapters 13 and 17 make it clear that it rejects any form of intervention by governments, politicians, media, or other third parties. On the other hand, the Ministry of Youth and Sports is also authorized by law to regulate sports activities generally within the scope of the State of Indonesia. The problems to be studied in this research are as follows: Firstly, what is the authority and role of the government in organizing professional football sport in Indonesia ?, Secondly, how is the implementation of football competition in Indonesia with the existence of PSSI Freezing ?. Research Methods in this paper using the method of normative juridical. The conclusion of this research is that the Government does not have the authority to intervene and interfere in organizing professional football competition in Indonesia. Meanwhile, with the freezing of this PSSI, automatically stop the league because PSSI can not perform the duties and functions to hold a professional football competition in Indonesia. The author's suggestion in this research is the Government must be optimal in providing services and convenience to PSSI and PSSI must be transparent in organizing professional football competition in Indonesia.

\section{Keywords: Authority, Government, PSSI}

\section{PENDAHULUAN}

Setiap negara mengakui bahwa olahraga menjadi suatu yang tidak bisa dipisahkan dari kehidupan manusia. Olahraga telah menjadi kebutuhan hidup bagi masyarakat semua bangsa dan negara yang ada di dunia. Negara yang masyarakatnya sangat gemar berolahraga akan mempunyai kecenderungan berada pada tingkat kesejahteraan umum yang lebih baik dibandingkan negara yang tidak gemar berolahraga. ${ }^{1}$ Bahkan dewasa ini prestasi olahraga suatu negara dapat dijadikan sebagai cermin terkait dengan kemajuan sebuah negara, karena negara dalam hal ini mengambil peran penting untuk membangun infrastrukturinfrastruktur yang bisa digunakan oleh masyarakat untuk berolahraga, baik bagi masyarakat secara umum maupun juga digunakan oleh atlet profesional dalam sebuah negara. ${ }^{2}$

${ }^{1}$ Toho Cholik Mutohir dan Ali Maksum, Sport Development Index : Alaternatif baru Mengukur Kemajuan Pembangunan Bidang Olahraga (Konsep, Metodologi, dan Aplikasi), ( Jakarta: Penerbit Indeks, 2007), hal. 5.

${ }^{2}$ Hinca IP Panjaitan, Kedaulatan Negara vs Kedaulatan FIFA, Bagaimana Mendudukan Masalah PSSI dan Negara (Pemerintah Indonesia), ( Jakarta : Gramedia, 2011), hal. 3. 
Di negara-negara eropa, olahraga dijadikan sebagai sarana industri, bisnis, dan alat untuk mengangkat status sosial yang sangat ampuh. Sementara itu, bagi orang Afrika dan Asia, olahraga digunakan untuk meningkatkan rasa nasionalisme mereka. ${ }^{3}$ Sementara itu, jika kita tarik kepada negara kita. Indonesia menjadi salah satu negara yang sangat menggemari olahraga. Sebagaimana motto olahraga nasional kita yaitu "memasyarakatkan olahraga dan mengolahragakan masyarakat". Motto ini merupakan konsep dasar negara kita untuk mewujudkan secara nyata pembangunan manusia seutuhnya sekaligus menjadi konsep memajukan kesejahteraan umum. ${ }^{4}$ Hal ini semakin menekankan kepada kita, bahwa Indonesia juga sangat memperhatikan olahraga, dan juga termasuk bagian yang sangat penting untuk tercapainya salah satu tujuan negara kita, yakni memajukan kesejahteraan umum.

Jika kita melihat didalam masyarakat di Indonesia, akan banyak kita temui masyarakat kita yang gemar berolahraga, ada yang suka tenis, bulu tangkis, sepeda, bola volly, sepak takraw, lari, renang, berkuda, memanah dan lain sebagainya, tak terkecuali sepakbola. Jika kita kembali melihat bagaimana sejarahnya, Inggris merupakan negara pertama yang mengembangkan sepak bola modern. Inggris berhasil membakukan permainan sepakbola ini dalam bentuk yang kita kenal sekarang yang tersebar diseluruh dunia. Perkembangan sepak bola dunia juga tidak terlepas dari peran benua Eropa khususnya Eropa wilayah barat dan selatan yang telah menyebarkan permainan sepakbola hingga seluruh dunia. ${ }^{5}$ Jika kita melihat perkembangan sepak bola dinegara sepakbola seperti Inggris ${ }^{6}$, sepakbola secara ekstrem diibaratkan sudah seperti agama bagi mereka, sesuatu yang sangat mereka cintai dan klub sepakbola maupun timnas sepakbola sudah seperti madzab/alirannya oleh para pecinta/ pendukung sebuah klub di masing - masing

\footnotetext{
${ }^{3}$ Daniel Dhakidae, Olahraga Untuk Apa, ( Depok : Prisma, LP3ES, 1978), hal.1

${ }^{4}$ Ibid. hal.5

${ }^{5}$ Connie M. Anderson,dkk.,Afrika Gila Bola ( Politik Sepakbola tuan rumah Piala Dunia ), ( Depok : Kepik Ungu, 2010 ), hal. 13

${ }^{6}$ Inggris adalah negara yang assosiasi sepakbolanya yakni Football Asociation (FA) merupakan asosiasi sepak bola yang tertua didunia dan FA lah yang pertama kali membuat peraturan sepakbola
} 
kota di Inggris, dan selalu menjadi topik pembicaraan yang hangat tiap kali menjelang atau setelah pertandingan antar klub/ negara mereka dimainkan. ${ }^{7}$

Sepak bola dari masa ke masa selalu mengalami perkembangannya. Sejalan dengan perkembangan dan kemajuan persepakbolaan dunia, maka dibentuklah Federation International de Football Association yang selanjutnya disebut FIFA. Sebuah badan atau organisasi internasional yang menaungi sepak bola dunia. Dijelaskan dalam statuta FIFA tentang Name and Headquarters, "The Fédération Internationale de Football Association (FIFA) is an association registered in the Commercial Register in accordance with art. $60 \mathrm{ff}$. of the Swiss Civil Code." 8 Sementara itu dalam pengertian lain FIFA juga didefinisikan The Fédération Internationale de Football Association (FIFA) is an association governed by Swiss law founded in 1904 and based in Zurich. It has 211 member associations and its goal, enshrined in its Statutes, is the constant improvement of football. $^{9}$

Organisasi FIFA ini pada awalnya berdiri di Paris, Prancis pada 21 Mei 1904. FIFA berdiri berkat gagasan oleh dua tokoh sepak bola yaitu Henry Delaunay dan Jules Rimet. Pertemuan tersebut kemudian dihadiri oleh tujuh negara yaitu Denmark, Spanyol, Swedia, Swiss, Belgia dan Belanda. Negara-negara tersebut kemudian ditetapkan menjadi anggota FIFA yang pertama dalam sejarah sekaligus mengagkat Robert Guerin yang berasal dari Perancis sebagai Presiden FIFA pertama.

Permainan sepak bola terus mengalami kemajuan dari tahun ke tahun. Jika kita mengacu berdasarkan statistik yang ada, FIFA pada tahun 2006 mencoba menghitung jumlah orang yang bermain sepakbola didunia. Dan berdasarkan hitungan tersebut, FIFA mencatat ada sekitar 265 juta pemain sepakbola, dan lebih dari 90 persennya adalah kaum laki-laki. ${ }^{10}$ Sepakbola selalu mendapat tempat dalam hati masyarakat dunia. Karena sepakbola merupakan olahraga yang unik,

7 Andri Veno," Analisis Manajemen Kepemimpinan Melalui Aplikasi Swot Pada Organisasi Pssi (Persatuan Sepakbola Seluruh Indonesia)", Pusat Studi Penelitian Pengembangan Manajemen dan Bisnis, Volume 1, Nomor 1, Juni 2016: 1-9, hal 1

${ }^{8}$ FIFA, FIFA Statutes, ( Mauritius: FIFA, 2013 ). Ps. 1 angka (1)

${ }^{9}$ FIFA, Who we are ?, http://www.fifa.com/about-fifa/who-we-are/index.html, diakses pada tanggal 13 November 2018

${ }^{10}$ Simon Kuper dan Stefan Szymanski, Soccernomics, ( Jakarta : Erlangga, 2010 ), hal. 183 
perpaduan yang dari berbagai aspek, mulai dari keterampilan, skill, fanatisme, emosi, kesedihan dan kejayaan.

Seperti yang telah penulis uraikan diatas, Sepakbola telah menjadi sebuah kekuatan sosial yang sangat dahsyat yang mempengaruhi sendi-sendi dan tatanan masyarakat dan negara. Federation Internationale de Football Association (FIFA) sebagai induk organisasi sepakbola internasional cukup berhasil dalam mengorganisasikan dan membangun jembatan antar negara-negara anggotanya menjadi komunitas dunia tanpa dibatasi oleh batas-batas administrasi negara (boderless) melalui kegiatan sepakbola. ${ }^{11}$ FIFA mampu membuat aturan yang baik sehingga sepak bola bisa berjalan seiring dengan hukum yang ada di negara itu sendiri. Sebagai bukti nyata, FIFA telah berhasil menyelenggarakan beragam kompetisi, seperti Piala Dunia dengan peserta tim sepakbola antar negara (FIFA World Cup), Piala Konfederasi dengan peserta tim sepakbola antar federasi benua (FIFA Confederation Cup), dan Piala Dunia Antar Klub dengan peserta pemenang masing-masing kejuaraan antar klub benua (FIFA Club World Cup) dan kejuarankejuaraan lain yang semuanya dinaungi dibawah bendera FIFA.

Jika kita melihat negara kita Indonesia, sepak bola seperti telah menjadi candu bagi masyarakat Indonesia. Penilaian penulis ini tidak terlepas dari kenyataan yang ada melihat bagaimana antusiasme masyarakat Indonesia terhadap olahraga sepak bola. Banyaknya masyarakat dinegara ini tentu membuat banyak pihak yang menggantungkan nasibnya pada olahraga ini baik dari segi industri, komersialisasi, dan bahkan mata pencaharian. Walaupun menurut catatan sejarah, Indonesia belum pernah masuk dalam kejuaraan agung sepakbola dunia yaitu Piala Dunia (World Cup) semenjak kemerdekaannya tahun 1945. Akan tetapi harapan penikmat sepak bola tanah air ini tidak pernah berhenti berharap dan tak pernah berhenti bermimpi agar suatu saat nanti, Tim Nasional (Timnas) Indonesia bisa menjadi kekuatan menakutkan dan disegani oleh dunia karena sepakbolanya.

Seiring berjalannya waktu, sepak bola Indonesia saat ini bukan lagi hanya sekedar olahraga, akan tetapi juga mempengaruhi bidang-bidang lain seperti sosial keagamaan, teknologi informasi, hiburan, ekonomi, bisnis, dan juga bahkan politik

\footnotetext{
${ }^{11}$ Hinca IP Panjaitan, Op.cit, hal. 1.
} 
yang juga menyeret para elit politik dalam suatu negara. ${ }^{12}$ Politik dan olahraga adalah dua bidang yang seharusnya berbeda dan tak bisa dicampur-adukkan. Namun pada kenyataannya dua bidang berbeda genre ini justru disatukan di Indonesia. Banyak para elit politik berusaha menunggangi sepak bola untuk memperoleh dukungan politik mereka, seperti dalam mencalonkan pemilihan gubernur misalnya, para elit politik tersebut masuk kedalam dunia sepak bola Indonesia bukan untuk memajukan sepak bola di Indonesia, akan tetapi justru sebagai bacu loncatan untuk karir politiknya di negeri ini.

Sepakbola di Indonesia memang bukan lagi hanya sekedar permainan. Tidak lagi soal menendang dan menyudul bola. Ada gairah lain didalamnya, sepak bola kini juga bicara tentang identitas, tentang ekonomi, dan tidak terkecuali politik. Sepakbola Indonesia selalu lekat dengan politik. ${ }^{13}$ Menurut penulis, sepakbola harusnya tetaplah menjadi sebuah olahraga tanpa embel-embel politik didalamnya. Karena sepakbola mampu mengumpulkan massa yang sangat besar dan lebih dari sekedar olahraga. Bahkan setiap tim punya slogan pemersatu mereka, sehingga semakin menjelaskan kepada kita bahwa sepakbola bukan hanya sekedar olahraga. Siapa yang tidak mengenal Liverpool dengan slogan "You'll Never Walk Alone" mereka, arti kata ini memang sangat dalam, bila kita hayati semakin menggambarkan bagaiamana sebuah klub sepak bola sudah tidak bisa dipisahkan dari kehidupan mereka.

Dilain hal, Indonesia mempunyai induk organisasi cabang olahraga sepakbola Indonesia yaitu Persatuan Sepakbola Seluruh Indonesia, selanjutnya disebut PSSI. Organisasi PSSI adalah satu-satunya organisasi sepakbola yang bersifat nasional yang berwenang mengatur, mengurus dan menyelenggarakan semua kegiatan atau kompetisi sepakbola di Indonesia. ${ }^{14}$ Soeratin Sosroseogondo dengan tujuh perwakilan dari Jogjakarta, Solo, Surabaya, Madiun, Magelang, Bandung, dan Jakarta ${ }^{15}$ telah memproklamirkan lahirnya Persatuan Sepakbola Seluruh Indonesia yang selanjutnya disebut PSSI, pada tanggal 19 April 1930 di Yogyakarta. PSSI merupakan suatu organisasi olahraga yang dilahirkan pada

12 Arif Natakusumah, Drama it bernama sepakbola. ( Jakarta : PT. Elex Media Komputindo. 2008) hal. 19

${ }^{13}$ Miftakhul.F.S, Mencintai sepakbola Indonesia meski kusut, (Yogyakarta : Indie book corner, 2016 ) hal.89

${ }_{14}^{14}$ Indonesia, Statuta PSSI, (Jakarta : PSSI : 2010) Ps.3 ayat (4)

${ }^{15}$ Miftakhul. F.S, Op.cit. hal.89 
zaman penjajahan Belanda. Tujuan didirikannya PSSI adalah untuk kegiatan politik demi menentang penjajahan Belanda pada saat itu. Jadi tidak heran sampai detik ini pun PSSI penuh dengan nuansa politik didalamnya. Jika dulu sepakbola digunakan sebagai alat pemersatu bangsa Indonesia, sekarang justru dijadikan sebagai alat merebut kekuasaan. ${ }^{16}$

PSSI memang dibentuk sebagai bentuk perlawanan bagi pemerintah Hindia Belanda baik secara langsung maupun tidak langsung, PSSI digunakan sebagai alat untuk menentang penjajahan dengan strategi menanamkan jiwa nasionalisme bagi para pemuda Indonesia. PSSI menjadi sarana menggugah nasionalisme sekaligus alat pemersatu bangsa. ${ }^{17}$ Namun dalam pelaksanaan dan pengaturannya, PSSI sejatinya akan berpedoman pada aturan dari FIFA (The Federation Internationale De Football Association) yang merupakan induk organisasi dan satu-satunya organisasi sepakbola dunia dimana PSSI menjadi salah satu anggotanya. ${ }^{18}$ Hal ini bukan berarti PSSI lepas dari hukum perudang-undangan yang ada di Indonesia, PSSI tetaplah harus mematuhi aturan yang berlaku di Indonesia dalam menjalankan roda organisasinya maupun juga roda kompetisi.

PSSI terus mengalami perubahan dan juga perkembangan sejak didirikannya pada tahun 1930. Akan tetapi pada tanggal 30 Mei 2015, FIFA selaku induk tertinggi organisasi sepakbola internasional akhrinya menjatuhkan sanksi (suspension) kepada PSSI. Hal tersebut terjadi karena FIFA menilai adanya intervensi yang dilakukan pemerintah melalui Kemenpora yang melakukan pembekuan terhadap organisasi PSSI. Terhitung sejak tanggal 27 april 2017, PSSI tidak diakui kegiatannya oleh Kemenpora melalui Keputusan Menpora Nomor : 01307 Tahun 2015 tentang Pengenaan Sanksi Administratif berupa kegiatan keolahragaan Persatuan Sepak Bola Seluruh Indonesia tidak diakui. Akibat masalah ini timbul berbagai perdebatan mengenai institusi tertinggi sepakbola yakni FIFA dan implikasi ataupun problematika yang muncul akibat sanksi tersebut. Indonesia dalam hal ini tidak diperbolehkan oleh FIFA untuk mengikuti agenda FIFA dan

${ }^{16}$ Ibid.

17 Pssi, Sejarah PSSI, http://www.pssi-football.com/id/view.php?page=pssi\#, diakses pada tanggal 13 november 2018.

${ }^{18}$ Ibid, Ps. 1 ayat (1) 
juga tidak lagi mendapat bantuan maupun dukungan dari FIFA untuk menjalankan kompetisi secara resmi.

Permasalahan ini dimulai pada saat pemerintah berusaha melaksanakan apa yang disebut dengan fungsi " pengawasan dan pembinaan " kepada induk organisasi cabang olahraga yang berbentuk badan hukum. Pengawasan yang dilakukan Kemenpora tersebut menimbulkan pertanyaan, apakah kebijakan pemerintah melalui kementerian pemuda dan olahraga mempunyai wewenang untuk mengeluarkan Keputusan Tata Usaha Negara ( KTUN ) Nomor 01307 Tahun 2015 tanggal 17 April 2015 yang berisi tentang Pengenaan Sanksi Administratif Berupa Kegiatan Keolahragaan Persatuan Sepakbola Seluruh Indonesia tidak diakui adalah suatu hal yang melawan hukum dan melampaui wewenangnya atau telah sesusai dengan peraturan perundang-undangan yang berlaku.

Jika kita mengacu pada Peraturan Pemerintah (selanjutnya disebut PP) No. 16 tahun 2007 tentang Penyelenggaraan Keolahragaan, pada pasal 36 ayat (1) dijelaskan bahwa "Pembinaan dan pengembangan olahraga profesional dilaksanakan dan diarahkan untuk terciptanya prestasi olahraga, lapangan kerja, dan peningkatan pendapatan."19 Lebih lanjut dalam pasal 36 ayat (2) dijelaskan bahwa "Pembinaan dan pengembangan olahraga profesional sebagaimana dimaksud pada ayat (1) dilakukan oleh induk organisasi cabang olahraga, induk organisasi olahraga fungsional, dan/atau organisasi olahraga profesional."20

Jika kita mengacu kepada kasus dan juga permasalahan yang dibahas, maka jelas pembinaan dan pengembangan olahraga sepak bola dalam hal ini harusnya telah menjadi tanggung jawab dari PSSI selaku induk organisasi cabang olahraga profesional sepak bola di Indonesia, dan pemerintah hanya berhak memfasilitasi kegiatan olahraga di Indonesia. Akan tetapi baik pihak Kemenpora dan PSSI menilai sama-sama memiliki kewenangan dan pengelolaan sepak bola di Indonesia. Benturan kewenangan inilah yang harus diberikan solusi hukum yang tepat dan terarah.

Selanjutnya, yang jadi pertanyaan adalah apakah kebijakan yang dikeluarkan dengan tidak mengakui seluruh kegiatan keolahragaan yang dilaksanakan PSSI selaku penyelenggara sepak bola tertinggi di negeri ini sudah

${ }^{19}$ Indonesia, Peraturan Pemerintah tentang Penyelenggaraan Keolahragaan, PP No. 16 tahun 2007. LN No.35, Ps. 36 ayat (1)

${ }^{20}$ Ibid. Ps. 36 ayat (2) 
tepat ataukah belum. Permasalahan ini menjadi pembahasan yang sangat menarik menurut penulis. Oleh karena itu, penulis ingin menganalisa permasalahan sebagai berikut :

1. Bagaimana kewenangan dan peran Pemerintah dalam penyelenggaraan olahraga sepak bola di Indonesia?

2. Bagaimana penyelenggaraan kompetisi sepak bola di Indonesia dengan adanya Pembekuan PSSI

\section{METODE PENELITIAN}

Agar penyusunan penulisan ini dapat terarah dan tidak menyimpang, maka harus dilakukan berdasarkan metode-metode tertentu. Hal ini disebabkan, suatu penelitian merupakan usaha untuk menemukan, mengembangkan dan menguji kebenaran suatu pengetahuan.

1. Bentuk Penelitian, Penelitian dalam penulisan ini menggunakan metode pendekatan yang digunakan bersifat yuridis normatif. Spesifikasi penelitian dalam penulisan ini adalah bersifat deskriptif analitis, dimana analisis dilakukan secara kritis dengan menggunakan berbagai teori tekait dengan permasalahan yang diangkat.

2. Tipologi Penelitian. Penelitian ini menggunakan tipologi preskriptif analitis yakni memberikan saran, penyelesaian, usulan, premis baru

3. Jenis Data, data yang digunakan dalam penelitian ini data sekunder.

4. Bahan Hukum yang digunakan mencakup : ${ }^{21}$

a. Bahan Hukum Primer, yaitu bahan-bahan hukum yang mengikat, dan terdiri dari, undang-undang 3 Tahun 2005 tentang Sistem Keolahragaan Nasional, Peraturan Pemerintah No. 16 tahun 2007 tentang Penyelenggaraan Keolahragaan, Peraturan Menteri Pemuda dan Olahraga, Peraturan Pemerintah Nomor 17 Tahun 2007 tentang Penyelenggaraan Pekan dan Kejuaraan Olahraga, Peraturan Pemerintah Nomor 18 Tahun 2007 tentang Pendanaan Olahraga, Peraturan Presiden

${ }^{21}$ Soerjono Soekanto dan Sri Mamudji, Penelitian Hukum Normatif (Jakarta : Raja Grafindo Persada, 2009), hal 13 
Nomor 22 Tahun 2010 tentang Program Indonesia Emas, Peraturan Presiden Nomor 7 Tahun 2015 tentang Organisasi Kementerian Negara, Peraturan Menteri Negara Pemuda dan Olahraga Nomor Statuta FIFA, dan Statuta PSSI.

b. Bahan Hukum Sekunder, yaitu bahan-bahan hukum yang mendukung bahan hukum primer, seperti buku, jurnal, hasil-hasil penelitian, seperti buku dan jurnal terkait dengan persepakbolaan dunia maupun persepakbolaan di Indonesia dan yang paling utama tentu berkaitan dengan permasalahan yang diangkat.

c. Bahan Hukum Tertier, yakni bahan yang memberikan petunjuk maupun penjelasan terhadap bahan hukum promer dan sekunder dalam penelitian ini, seperti kamus hukum dan ensiklopedia sepak bola.

5. Alat pengumpulan data, Penelitian ini lebih menitikberatkan pada studi kepustakaan maupun studi dokumenter terhadap ketentuan peraturan perundang-undangan, statuta FIFA dan statuta PSSI.

6. Metode analisis data, metode analisa yang digunakan dalam penelitian ini adalah bersifat kualitatif, yakni kebenaran data/premis akhir ditentukan oleh penelitinya sendiri.

7. Bentuk hasil penelitian akan disajikan dalam bentuk preskriptif-analitis.

\section{PEMBAHASAN}

\section{A. Kewenangan dan peran Pemerintah dalam penyelenggaraan olahraga sepak bola di Indonesia}

Sebelum kita masuk kedalam pembahasan mengenai kewenangan dan peran pemerintah dalam penyelenggaraan sepak bola, akan lebih baik menurut penulis kita memahami terlebih dahulu mengenai Menteri sebagai bagian dari Pemerintah, dalam hal ini yang lebih spesifik tentunya Menteri Pemuda dan Olahraga. Menurut Jimly Asshidiqie, Menteri adalah pejabat tinggi yang memiliki peran yang sangat penting dan juga nyata dalam bertindak sebagai pimpinan pemerintahan yang sesuai ruang lingkup atau kementerian mereka masingmasing. ${ }^{22}$ Oleh sebab itu, dalam hal ini Kementerian Pemuda dan Olahraga juga

\footnotetext{
${ }^{22}$ Ibid
} 
memiliki kewenangan dalam mengambil suatu keputusan maupun juga suatu kebijakan untuk memajukan dan mensejahterakan di bidang keolahragaan di Indonesia. Adapun dasar hukumnya terdapat dalam Undang-undang Nomor 39 Tahun 2008 tentang Kementerian Negara, dijelaskan dalam pasal $4:{ }^{23}$

1. Setiap Menteri membidangi urasan tertentu dalam pemerintahan.

2. Urusan tertentudalam pemerintahan sebagaimana dimaksud pada ayat (1) terdiri atas:

a. Urusan pemerintahan yang nomenklatur Kementeriannya secara tegas disebutkan dalam Undang-Undang Dasar Negara Republik Indonesia Tahun 1945;

b. Urusan pemerintahan yang ruang lingkupnya disebutkan dalam Undang-undang Dasar Negara Republik Indonesia tahun 1945; dan

c. Urusan pemerintahan dalam rangka penajaman, koordinasi, dan sinkronisasi program pemerintah.

Hal ini juga yang mendasari Menpora sebagai perwakilan Pemerintah dalam hal ini mengeluarkan untuk membekukan PSSI, karena Menpora menilai PSSI masih dalam ruang lingkup olahraga di Indonesia dan Menpora merasa mempunyai kewenangan dalam mengelola dan juga menyelenggarakan sepak bola di Indonesia untuk memajukan dan mensejahterakan di bidang Keolahragaan. Jika kita melihat kasus pembekuan PSSI oleh Kemenpora, tentu untuk mengeluarkan sebuah kebijakan, Menpora memiliki landasan atas tindakannya tersebut. Akan tetapi menurut penulis, keputusan Menpora tersebut justru tidak sesuai dengan peraturan perundang-undangan yang berlaku.

Seperti yang telah penulis singgung sebelumnya, menurut analisa penulis, kewajiban Menpora dalam pengelolaan dan penyelenggaran sepak bola adalah hanya sebatas memberikan fasilitas penunjang untuk meningkatkan kualitas olahraga, seperti membuat stadion, membangun infrastruktur olahraga, mendukung secara finansial pengelolaan dan pembinaan usia dini untuk atlet dan lain sebagainya. Akan tetapi, Pemerintah tidak punya kewenangan untuk menyelenggarakan kompetisi dan ikut campur dalam menjalankan organisasi perkumpulan berbadan hukum perkumpulan sepak bola dalam sebuah negara.

${ }^{23}$ Indonesia, Undang-Undang Kementerian Negara, UU No. 39 tahun 2008, LN No. 166 tahun 2008 Ps. 4. 
Karena kompetisi sejatinya dikelola dan dilaksanakan oleh organisasi sepak bola yang sah dan diakui, dalam hal ini adalah PSSI. Karena didalam Undang-undang No. 3 tahun 2005 tentang Sistem Keolahragaan Nasional pada Pasal 27 menyatakan bahwa bahwa pembinaan dan pengembangan olahraga prestasi menjadi ranah wewenang induk organisasi cabang olahraga baik pada tingkat pusat maupun daerah. Dalam kasus ini maka yang berhak dalam menjalankan kompetisi sepak bola profesional di Indonesia adalah PSSI. ${ }^{24}$ Jadi kewenangan dalam menjalankan kompetisi sepak bola profesional di Indonesia bukan lagi menjadi kewenangan dari Kemenpora.

Pemerintah bisa mengoptimalkan perannya dalam hal menyediakan infrastuktur, lapangan, dan fasilitas lain untuk menunjang kinerja PSSI sebagai organisasi yang berwenang mengatur sepak bola. Sebagaimana fungsi pemerintahan menurut Rasyid sebagaimana dikutip Delly Mustafa terbagi menjadi 4 bagian yaitu $:^{25}$

1. Fungsi Pelayanan ( Public Service)

2. Fungsi Pembangunan (Development)

3. Fungsi pemberdayaan (empowering)

4. Fungsi pengaturan ( regulation)

Lebih lanjut menurut Rasyid, untuk mengatahui dan juga menilai bagaimana suatu masyarakat dalam sebuah negara maka kita bisa lihat bagaimana kinerja dari pemerintahannya. Fungsi-fungsi pemerintahan yang dijalankan dengan baik maka akan menggambarkan bagaimana kualitas dari pemerintah itu sendiri. Karena pemerintah diadakan untuk kepentingan masyarakat dan bukan untuk kepentingannya sendiri. ${ }^{26}$

Walaupun sanksi seperti ini bukanlah hal baru dalam sepakbola dunia, tercatat beberapa negara pernah mengalami hal yang sama seperti yang dialami indonesia. Dalam pengelolaan dan juga penyelenggaraan sebuah kompetisi sepakbola, FIFA mengambil alih seluruh kebijakan dan tidak mau diintervensi oleh negara dalam hal pengelolaan dan penyelenggaraan. Karena FIFA memiliki rule of the game tentang bagaimana mengatur anggotanya. Lebih lanjut

${ }^{24}$ Indonesia, Undang-undang sistem keolahragaan nasional, Ps. 27.

${ }^{25}$ Rasyid dalam Delly Mustafa, Birokrasi Pemerintahan ( ed.revisi), ( Bandung : Alfabeta, 2014 ), hal. 100-101.

${ }^{26}$ Ibid 
dijelaskan Statuta FIFA dalam pasal 13 tentang kewajiban anggota, huruf (g) menyebutkan bahwa "seluruh anggota FIFA harus selalu memastikan bahwa seluruh aktivitas organisasi tidak diintervensi atau bebas dari campur tangan pihak ketiga" (To manage their affairs independently and ensure that ther own affairs are not influenced by any third parties). ${ }^{28}$

Kewajiban menjaga independensi asosiasi sepakbola dalam sebuah negara juga kembali ditekankan oleh FIFA dalam Statuta FIFA pasal. 17 ayat (2), dijelaskan bahwa "setiap anggota harus mengelola semua urusannya secara independen dan tanpa pengaruh dari pihak ketiga" (Each member shall manage its affairs independently and with no influence third parties). ${ }^{29}$ Namun dalam pelaksanaannya, ada saja peran negara yang mencoba untuk mengintervesi induk sepakbola dalam sebuah negara. Hal inilah yang menyebabkan FIFA tidak segan dalam menjatuhkan sanksi kepada negara yang ikut mengintervensi anggotanya. ${ }^{30}$

Dalam Statuta FIFA menjelaskan bahwa menolak segala bentuk intervensi yang dilakukan oleh pemerintah, politisi, media, atau pihak ketiga lainnya. FIFA akan membekukan sebuah organisasi sepakbola disuatu negara dan juga melarang aktivitas sepakbola di negara tersebut jika tidak mengindahkan perintah dari FIFA. Sebelum kasus yang menimpa Indonesia, hal ini juga terjadi dengan negara Yunani. Bahkan dalam kasus asosiasi sepakbola HFF Yunani, dimana pemerintah dan parlemen Yunani menyerah terhadap kemauan FIFA yang mendesak Yunani agar Undang-Undang yang disahkan oleh pemerintah Yunani dikecualikan bagi HFF selaku anggota dari FIFA dan UEFA. ${ }^{31}$

Pemerintah pada dasarnya tidak punya kewenangan untuk melakukan intervensi dan ikut campur dalam menjalakan roda organisasi PSSI. Karena kompetisi sejatinya dikelola dan dilaksanakan oleh organisasi sepak bola yang sah dan diakui oleh FIFA, dalam hal ini adalah PSSI. PSSI sebagai cabang induk olahraga sepak bola mempunyai kewenangan secara atributif sebagaimana diamanatkan Undang-undang Sistem Keolahragaan Nasional Pasal 29 sehingga Kemenpora tidak dapat sewenang - wenang menjatuhkan sanksi administratif

\footnotetext{
${ }^{27}$ FIFA, Op.cit, Ps. 13 huruf (g)

${ }^{28}$ Ibid. ps. 13

${ }^{29}$ Ibid. Ps. 17 ayat 2

${ }^{30}$ Hinca IP Panjaitan, Op.cit, hal.306

${ }^{31}$ Ibid. hal 306-307
} 
kepada PSSI. Pemerintah bisa mengoptimalkan perannya dalam mendukung seluruh kegiatan sepak bola dan juga bisa melakukan pengawasan terhadap penyelenggaraan sepak bola bukan melakukan intervensi apalagi dengan tidak mengakui seluruh kegiatan keolahragaan yang diselenggarakan PSSI, karena mengenai tata cara memberikan sanksi administratif ini sendiri juga tidak diatur dalam undang-undang sistem keolahragaan nasional dan juga peraturan perundang-undangan yang lain tentang keolahragaan. Oleh karena itu PSSI dalam dalam menjalankan tugas-tugas dan fungsinya diperlukan suatu independensi

Pemerintah tidak boleh ikut campur kedalam organisasi perkumpulan berbadan hukum perkumpulan seperti PSSI, karena itu bukan kewenangan Pemerintah yang dalam hal ini diwakili pihak Kemenpora. Pemerintah tidak berhak ikut campur dalam pemilihan ketua umum, penunjukkan pelatih tim nasional, penentuan struktur organisasi PSSI dan lain sebagainya, hal ini dikarenakan perbuatan tersebut akan melanggar peraturan perundang-undangan yang ada. Karena jika mengacu kepada peraturan perundang-undangan yang berlaku, PSSI bukanlah bawahan dari Kemenpora.

\section{B. Penyelenggaraan kompetisi sepak bola di Indonesia dengan adanya Pembekuan PSSI}

Dalam pengelolaan dan penyelenggaran sepak bola yang profesional. FIFA selaku otoritas sepak bola dunia menolak adanya intervensi dari pihak ketiga, baik itu pemerintah, media, politisi dan lainya. Akan tetapi didalam pelaksanaannya masih banyak negara-negara yang tidak mematuhi permasalahan tersebut, akhirnya FIFA memberikan teguran kepada negara yang melakukan intervensi atau ikut campur kepada organisasi sepak bola di negara tersebut. FIFA melalui statuta FIFA melarang keras adanya intervensi tersebut. Karena FIFA memiliki rule of the game tentang bagaimana mengatur anggotanya.

Hal tersebut dijelaskan Statuta FIFA dalam pasal 13 tentang kewajiban anggota, huruf (g) menyebutkan bahwa" "seluruh anggota FIFA harus selalu memastikan bahwa seluruh aktivitas organisasi tidak diintervensi atau bebas dari campur tangan pihak ketiga" (To manage their affairs independently and ensure

\footnotetext{
${ }^{32}$ FIFA, FIFA Statutes, Ps. 13 huruf (g).
} 
that ther own affairs are not influenced by any third parties). ${ }^{33}$ Kewajiban sebuah organisasi yang menjadi anggota dari FIFA juga harus menjaga independensi dalam sebuah negara juga kembali ditekankan oleh FIFA dalam Statuta FIFA pasal. 17 ayat (2), dijelaskan bahwa "setiap anggota harus mengelola semua urusannya secara independen dan tanpa pengaruh dari pihak ketiga" (Each member shall manage its affairs independently and with no influence third parties).${ }^{34}$ Namun dalam pelaksanaannya, ada saja peran negara yang mencoba untuk mengintervesi induk sepakbola dalam sebuah negara. Hal inilah yang membuat FIFA akan menjatuhkan sanksi kepada negara yang ikut mengintervensi anggotanya. ${ }^{35}$

Dengan adanya Pembekuan PSSI oleh Menpora, maka PSSI memutuskan untuk menghentikan kompetisi terkait situasi force majeure. Penghentian kompetisi Liga Indonesia semata-mata untuk menyelamatkan klub-klub sepak bola Indonesia. PSSI memang terpaksa harus mengambil keputusan menghentikan kompetisi Liga Indonesia, setelah dinilai ada berbagai intervensi yang dilakukan oleh pihak Kemenpora melalui Menpora Imam Nahrawi. Dalam pembahasan kedua ini bisa kita tarik point penting bahwa penyelenggaraan kompetisi akan berhenti jika terjadi ikut campur atau intervensi dari pihak pemerintah.

Oleh karena itu, dalam pengelolaan dan penyelenggaran sepak bola di Indonesia, haruslah dilakukan oleh orang-orang yang profesional dibidang olahraga sepak bola dan mengerti bagaimana manajemen olahraga sepak bola. Bukan diisi oleh orang-orang yang tidak mengerti sepak bola seperti halnya para politisi, hingga elit politik dinegeri ini yang ikut berebut kekuasaan untuk memimpin PSSI, sehingga tidak heran banyak sekali mafia sepak bola, pengaturan skor, hingga sepak bola gajah yang terjadi dalam sepak bola Indonesia. Perlu menjadi catatan dari para petinggi sepak bola di Indonesia bahwa kompetisi yang sehat, yang baik, yang profesional akan melahirkan tim nasional yang juga tangguh. Begitu pula sebaliknya, jika sepak bola hanya dijadikan

\footnotetext{
${ }^{33}$ Ibid. ps. 13

${ }^{34}$ Ibid. Ps. 17 ayat 2

${ }^{35}$ Hinca IP Panjaitan, Kedaulatan Negara vs Kedaulatan FIFA, hal.306.
} 
sebagai batu loncatan untuk menggapai kekuasaan, maka sepak bola Indonesia akan sulit berkembang dari masa ke masa.

\section{PENUTUP}

\section{A. Simpulan}

Berdasarkan analisis dalam tulisan ini maka dapat disimpulkan berbagai hal, seperti berikut :

1. Kewenangan dan Peran Pemerintah dalam pengelolaan dan penyelenggaran sepak bola di Indonesia adalah mengawal dan memberikan fasilitas penunjang untuk meningkatkan kualitas olahraga, seperti membuat stadion, membangun infrastruktur olahraga, mendukung secara finansial pengelolaan dan pembinaan usia dini untuk atlit dan lain sebagainya. Pemerintah berkewajiban memberikan pelayanan dan kemudahan kepada induk organisasi cabang olahraga dalam menyelenggarakan sepak bola di Indonesia. Akan tetapi, Pemerintah tidak punya kewenangan untuk melakukan intervensi dan ikut campur dalam menjalakan roda organisasi PSSI. Karena kompetisi sejatinya dikelola dan dilaksanakan oleh organisasi sepak bola yang sah dan diakui oleh FIFA, dalam hal ini adalah PSSI. PSSI sebagai cabang induk olahraga sepak bola mempunyai kewenangan secara atributif sebagaimana diamanatkan Undang-undang Sistem Keolahragaan Nasional Pasal 29 sehingga Kemenpora tidak dapat sewenang - wenang menjatuhkan sanksi administratif kepada PSSI. Pemerintah bisa mengoptimalkan perannya dalam mendukung seluruh kegiatan sepak bola dan juga bisa melakukan pengawasan terhadap penyelenggaraan sepak bola bukan melakukan intervensi apalagi dengan tidak mengakui seluruh kegiatan keolahragaan yang diselenggarakan PSSI, karena mengenai tata cara memberikan sanksi administratif ini sendiri juga tidak diatur dalam undang-undang sistem keolahragaan nasional dan juga peraturan perundang-undangan yang lain tentang keolahragaan. Oleh karena itu PSSI dalam dalam menjalankan tugas-tugas dan fungsinya diperlukan suatu independensi. Artinya tidak ada intervensi dari pihak 
manapun bagi PSSI ketika menjalankan roda organisasinya. PSSI harus bersifat netral terhadap perbedaan politik dan agama. Sehingga menurut penulis apabila kedua belah pihak bisa memahami kewenangannya masing-masing dan mampu bekerja sama akan berdampak positif terhadap kemajuan sepak bola di Indonesia.

2. Terkait dengan dampak dari pembekuan PSSI ini sangatlah besar, penulis mencatat ada beberapa dampak negatif dengan adanya pembekuan PSSI oleh pihak Kemenpora, antara lain setelah melakukan pembekuan PSSI, Menpora juga menyurati Kapolri dan juga para kepala-kepala daerah untuk tidak memberikan izin kelanjutan kompetisi. Langkah Menpora meminta kepala-kepala daerah dan kepolisian untuk tidak memberikan pelayanan kepada PSSI maupun PT Liga Indonesia membuat PSSI memutuskan untuk menghentikan Liga dengan alasan force majeure. Tidak hanya itu, kerugian juga berdampak terhadap liga, klub dan juga pemain, official, dan sejumlah pelaku bisnis, mengalami kerugian. Hal ini dikarenakan pembekuan PSSI ini secara otomatis juga menghentikan liga karena PSSI tidak bisa melaksanakan tugas dan fungsi untuk menyelenggarakan sepak bola Indonesia.

\section{B. Saran}

Adapun saran yang didapat penulis berikan dari hasil penelitian ini adalah sebagai berikut :

1. Pemerintah harus optimal dalam memberikan pelayanan dan kemudahan kepada PSSI untuk menjalankan kegiatan sepakbola seperti pembangunan stadion bertaraf internasional, fasilitas untuk atlit, dan lain sebagainya sementara itu disatu sisi Pemerintah juga bisa ikut ambil peran dalam menjaga independensi PSSI dengan tidak melakukan intervensi dan Pemerintah tidak boleh melakukan tindakan sewenangwenang kepada PSSI, karena Kemenpora seharusnya tidak boleh masuk dalam masalah internal suatu badan hukum perkumpulan dalam hal ini PSSI.

2. PSSI harus lebih transparan dalam menjalankan roda organisasinya, bukan justru tertutup dan selalu merasa diintervensi oleh pihak 
Kemenpora, beberapa permasalahan yang sering terjadi dan harus diselesaikan oleh PSSI antara lain seperti penyelesaian utang kepada pemain dan official team, kontrak kerja pemain lokal dan asing. Tidak hanya itu, hal yang lebih utama yang menjadi pekerjan rumah PSSI adalah PSSI harus menyelesaikan kasus match fixing, menyogok wasit, perkelahian antar suporter, dan juga peningkatan prestasi Tim Nasional Indonesia disegala umur.

\section{DAFTAR PUSTAKA}

\section{Buku:}

Anderson, Connie M. dkk.,Afrika Gila Bola (Politik Sepakbola tuan rumah Piala Dunia), Depok : Kepik Ungu, 2010

Dhakidae, Daniel, Olahraga Untuk Apa, Depok : Prisma, LP3ES, 1978.

Kuper, Simon dan Stefan Szymanski, Soccernomics, Jakarta : Erlangga, 2010.

Miftakhul.F.S, Mencintai sepakbola Indonesia meski kusut, Yogyakarta : Indie book corner, 2016.

Mustafa, Delly, Birokrasi Pemerintahan (ed.revisi), Bandung : Alfabeta, 2014

Mutohir, Toho Cholik dan Ali Maksum, Sport Development Index : Alaternatif baru Mengukur Kemajuan Pembangunan Bidang Olahraga (Konsep, Metodologi, dan Aplikasi), Jakarta: Penerbit Indeks, 2007.

Natakusumah, Arif, Drama it bernama sepakbola. Jakarta : PT. Elex Media Komputindo. 2008.

Panjaitan, Hinca IP, Kedaulatan Negara vs Kedaulatan FIFA, Bagaimana Mendudukan Masalah PSSI dan Negara (Pemerintah Indonesia), Jakarta : Gramedia, 2011.

Soekanto, Soerjono dan Sri Mamudji, Penelitian Hukum Normatif, Jakarta : Raja Grafindo Persada, 2009.

\section{Peraturan Perundang-undangan:}

FIFA, FIFA Statutes, Mauritius: FIFA, 2013.

Indonesia, Peraturan Pemerintah tentang Penyelenggaraan Keolahragaan, PP No. 16 tahun 2007. LN No.35. 
Indonesia, Statuta PSSI, Jakarta : PSSI : 2010.

Indonesia, Undang-Undang Kementerian Negara, UU No. 39 tahun 2008, LN No. 166 tahun 2008.

Indonesia, Undang-undang Sistem Keolahragaan Nasional, UU No. 3 tahun 2005, LN No. 89.

\section{Website:}

PSSI, Sejarah PSSI, http://www.pssi-football.com/id/view.php?page=pssi\#, diakses pada tanggal 13 November 2018

FIFA, Who we are ?, http://www.fifa.com/about-fifa/who-we-are/index.html, diakses pada pada tanggal 13 November 2018. 